University of South Florida

DIGITAL COMMONS

Digital Commons @ University of

@ UNIVERSITY OF SOUTH FLORIDA

South Florida

$1-1-2016$

\title{
2016 Accountability Report USF Sarasota-Manatee
}

USF

Follow this and additional works at: https://digitalcommons.usf.edu/usf_accountability_reports

\section{Scholar Commons Citation}

USF, "2016 Accountability Report USF Sarasota-Manatee" (2016). USF Accountability Reports. 57.

https://digitalcommons.usf.edu/usf_accountability_reports/57

This Article is brought to you for free and open access by the USF Archives at Digital Commons @ University of South Florida. It has been accepted for inclusion in USF Accountability Reports by an authorized administrator of Digital Commons @ University of South Florida. For more information, please contact digitalcommons@usf.edu. 


\section{5-16}

\section{Annual Accountability Report}

\section{UNIVERSITY OF SOUTH FLORIDA- SARASOTA-MANATEE}

STATE UNIVERSITY SYSTEM of FLORIDA Board of Governors 


\section{TABLE OF CONTENTS}

\section{EXECUTIVE SUMMARY}

DASHBOARD

KEY ACHIEVEMENTS

NARRATIVE

\section{DATA TABLES}

SECTION 1. FINANCIAL RESOURCES

SECTION 2. PERSONNEL

SECTION 3. ENROLLMENT

SECTION 4. UNDERGRADUATE EDUCATION

SECTION 5. GRADUATE EDUCATION

SECTION 6. RESEARCH \& ECONOMIC DEVELOPMENT p. 2

p. 5

p. 7

p. 11

p. 15

p. 16

p. 20

p. 28

p. 30 


\section{Dashboard}

\begin{tabular}{|c|c|c|c|c|c|c|c|c|}
\hline $\begin{array}{l}\text { Headcount } \\
\text { Enrollments }\end{array}$ & $\begin{array}{l}\text { Fall } \\
2015\end{array}$ & $\begin{array}{c}\% \\
\text { Total }\end{array}$ & $\begin{array}{l}\text { 2014-2015 } \\
\text { \% Change }\end{array}$ & \multicolumn{3}{|c|}{ Degree Programs Offered } & \multicolumn{2}{|c|}{2012 Carnegie Classifications } \\
\hline TOTAL & 2,044 & $100 \%$ & $7 \%$ & \multicolumn{2}{|c|}{ TOTAL (as of Sprina 2016) } & 26 & \multirow{2}{*}{ Basic: } & \multirow{2}{*}{$\begin{array}{l}\text { Master's Colleges \& } \\
\text { Universities: Small }\end{array}$} \\
\hline White & 1,438 & $70 \%$ & $5 \%$ & \multicolumn{2}{|l|}{ Baccalaureate } & 18 & & \\
\hline Hispanic & 292 & $14 \%$ & $10 \%$ & \multicolumn{2}{|l|}{ Master's } & 8 & \multirow{2}{*}{\begin{tabular}{c|} 
Undergraduate \\
Instructional Program:
\end{tabular}} & \multirow{2}{*}{$\begin{array}{l}\text { Balanced arts \& } \\
\text { sciences/professions, } \\
\text { some graduate }\end{array}$} \\
\hline Black & 116 & $6 \%$ & $-6 \%$ & \multicolumn{2}{|l|}{ Research Doctorate } & 0 & & \\
\hline Other & 198 & $10 \%$ & $21 \%$ & \multicolumn{2}{|c|}{ Professional Doctorate } & 0 & \multirow{2}{*}{$\begin{array}{c}\text { Graduate } \\
\text { Instructional Program: }\end{array}$} & \multirow{2}{*}{$\begin{array}{l}\text { Postbaccalaureate: } \\
\text { Education-dominant, with } \\
\text { other professional program }\end{array}$} \\
\hline Full-Time & 1,042 & $51 \%$ & $12 \%$ & \multirow{2}{*}{$\begin{array}{c}\text { Faculty } \\
\text { (Fall 2015) }\end{array}$} & \multirow{2}{*}{$\begin{array}{l}\text { Full- } \\
\text { Time }\end{array}$} & \multirow{2}{*}{$\begin{array}{l}\text { Part- } \\
\text { Time }\end{array}$} & & \\
\hline Part-Time & 1,002 & $49 \%$ & $1 \%$ & & & & \multirow{2}{*}{$\begin{array}{c}\text { Four-year, small, } \\
\text { primarily nonresidential }\end{array}$} & \multirow{2}{*}{$\begin{array}{c}\text { Four-year, small, } \\
\text { primarily nonresidential }\end{array}$} \\
\hline Undergraduate & 1,757 & $86 \%$ & $4 \%$ & TOTAL & 82 & 61 & & \\
\hline Graduate & 174 & $9 \%$ & $45 \%$ & Tenure \& Ten. Track & 37 & 0 & \multirow{2}{*}{$\begin{array}{l}\text { Community } \\
\text { Engagement: }\end{array}$} & \multirow{2}{*}{ No } \\
\hline Unclassified & 113 & $6 \%$ & $8 \%$ & Non-Tenured Faculty & 45 & 61 & & \\
\hline
\end{tabular}

DEGREE PRODUCTIVTYY AND PROGRAM EFFICIENCY
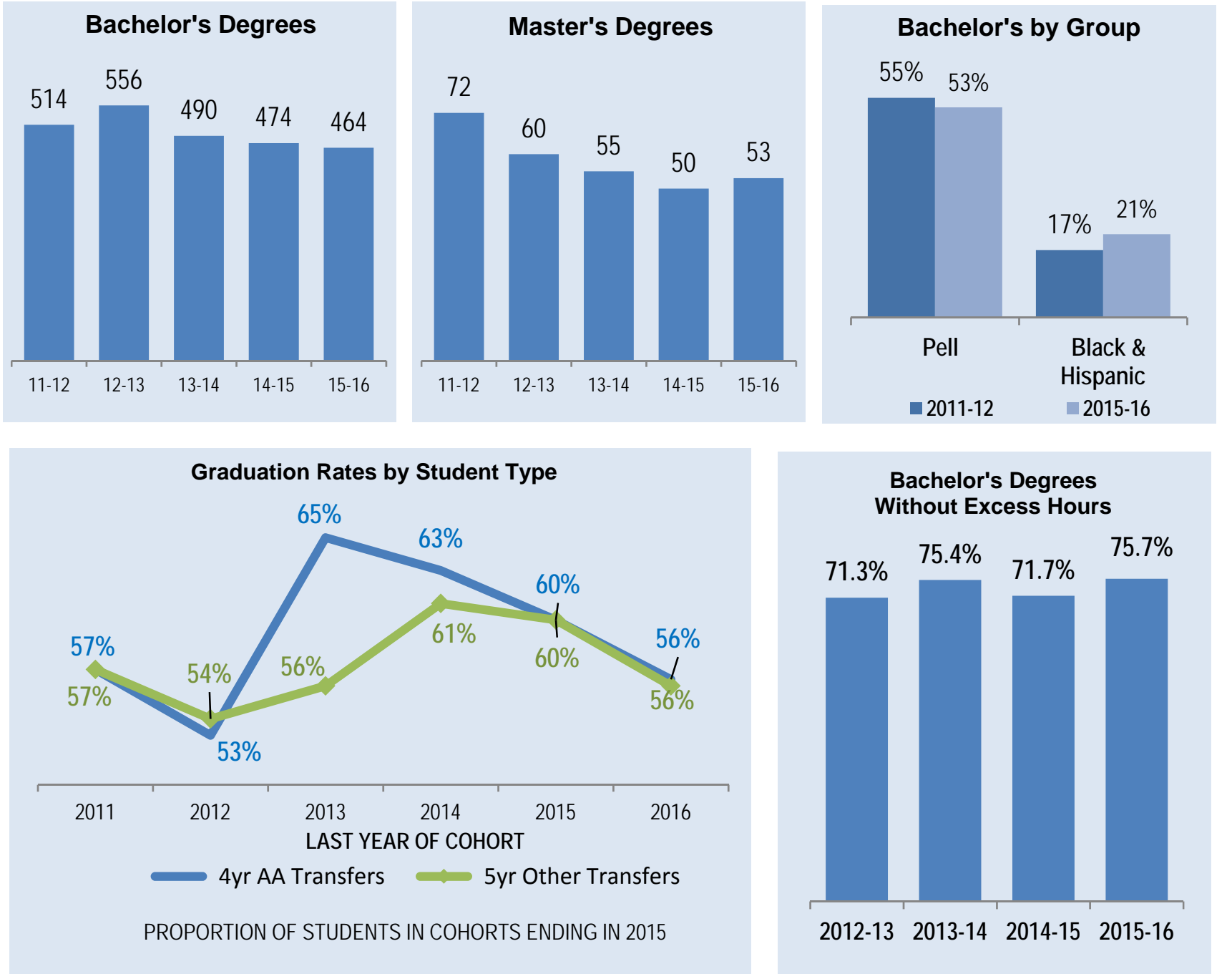


\section{Dashboard}

\section{DEGREES AWARDED IN PROGRAMS OF STRATEGIC EMPHASS}
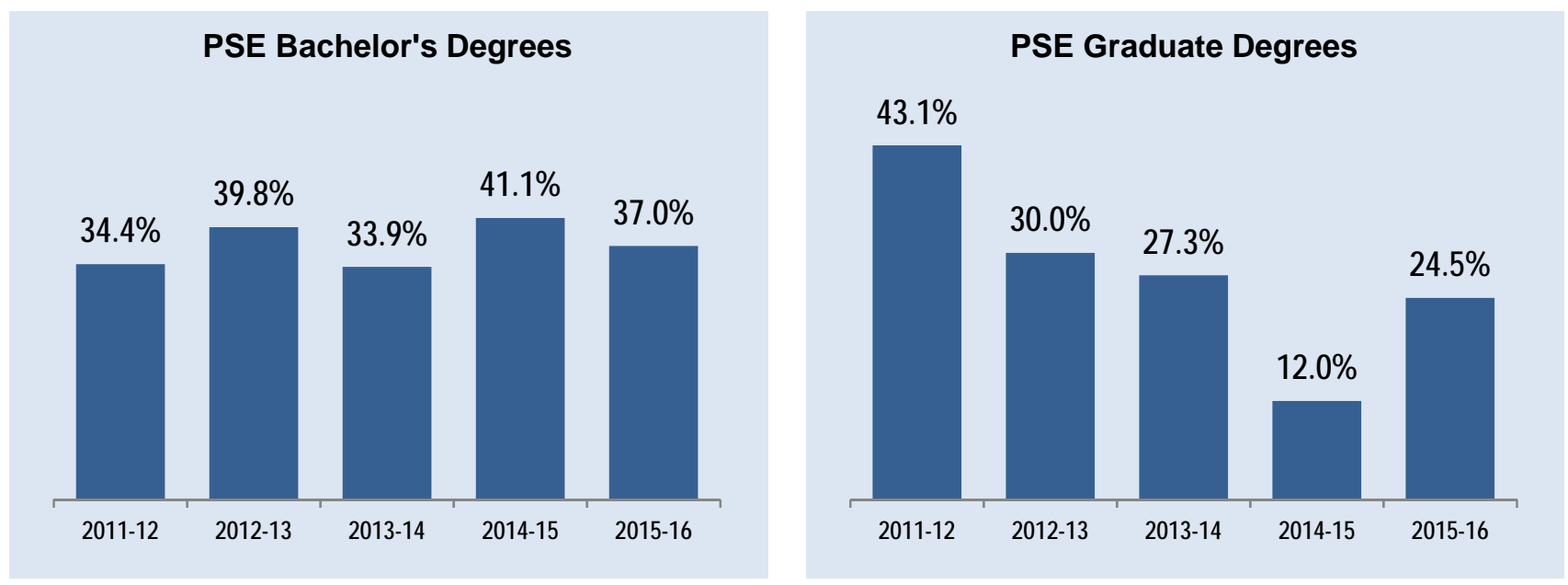

\section{RESEARCH AND COMMERCIALIZATION ACTIMTY}

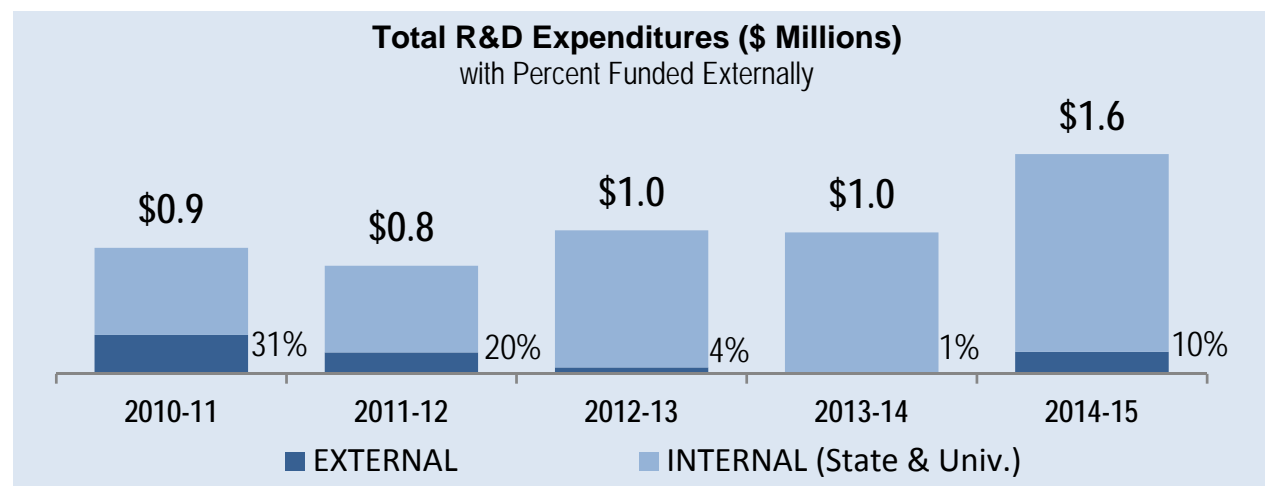

\section{RESOURCES}

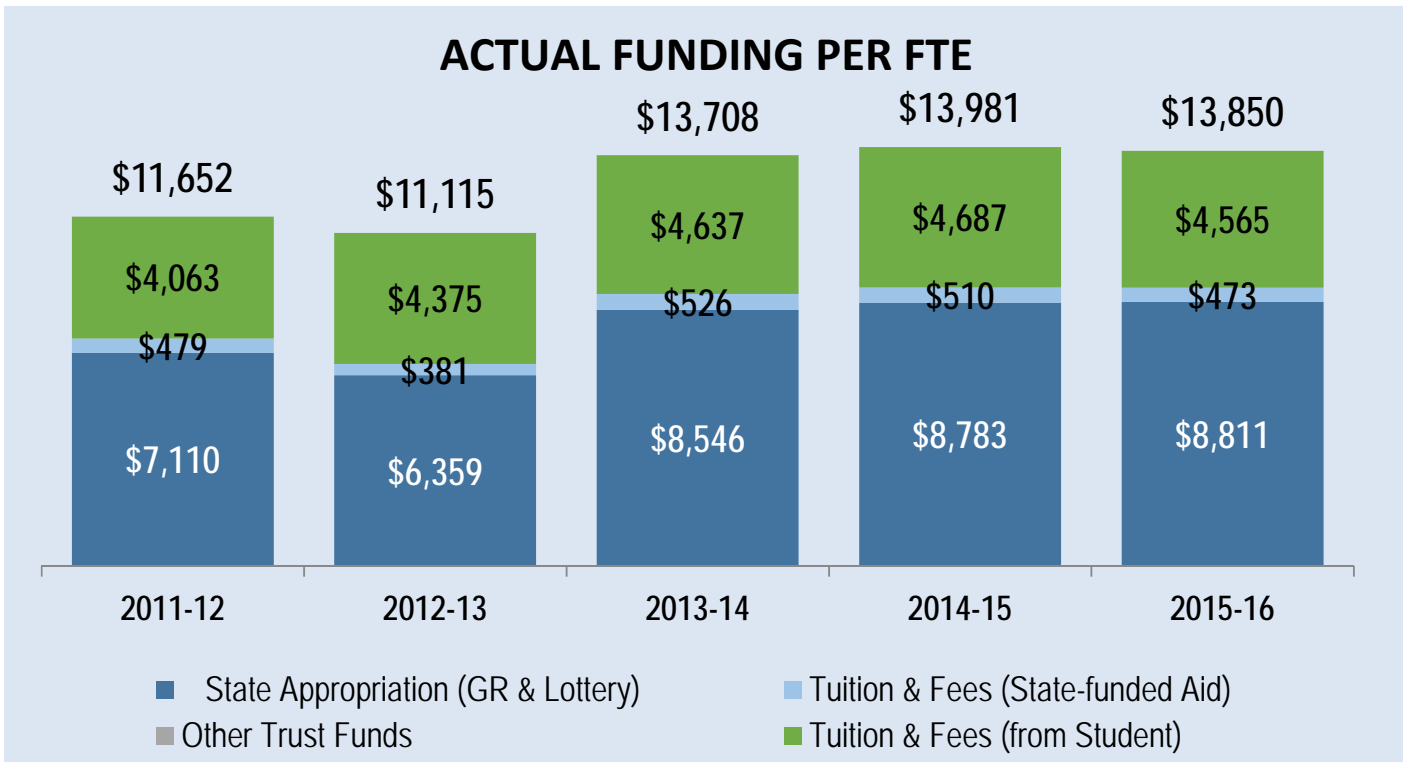

Note: Tuition and Fee revenues include tuition, tuition differential fee and E\&G fees (i.e., application, late registration, and library fees/fines) based on the actual amount collected (not budget authority) by universities as reported in their Operating Budget 625 reports. Other local fees that do not support $E \& G$ activities are not included here. Please note that a portion of the Tuition \& Fees is supported by federal SFA programs (ie, Pell grants). State-funded Student Financial Aid amounts include the 11 SFA programs that OSFA reports annually. State Appropriations includes General Revenues, Lottery and Other Trust funds (i.e., Federal Stimulus for 2009-10 and 2010-11 only) that are directly appropriated to the university as reported in Final Amendment Package. Student FTE are actual and based on the standard IPEDS definition of FTE (equal to 30 credit hours for undergraduates and 24 for graduates). This data does not include funds or FTE from special units (i.e., IFAS, Health-Science Centers or Medical Schools). Not adjusted for inflation. 


\section{Dashboard}

\section{POST-GRADUATION METRICS}

\section{Percent of Bachelor's Graduates \\ Employed (\$25,000+) or Enrolled One Year After Graduation}

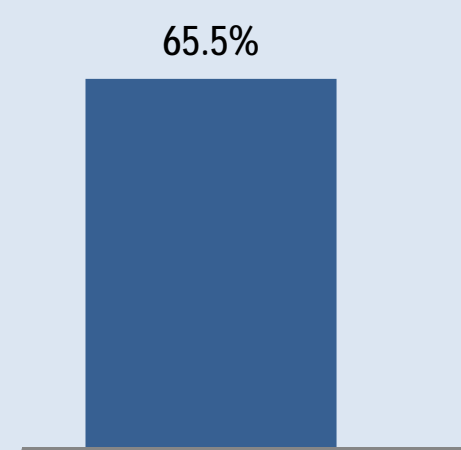

2012-13 GRADUATES
$62.8 \%$

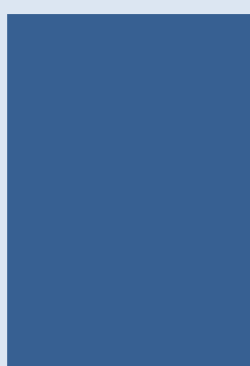

2013-14

GRADUATES
$69.6 \%$

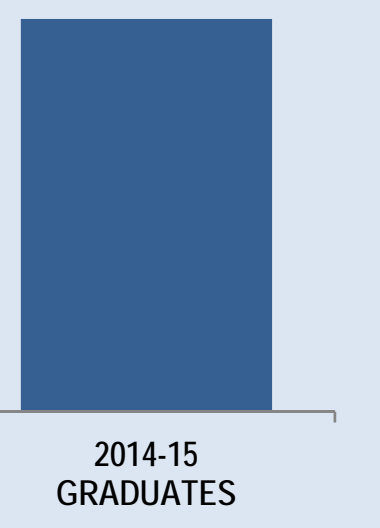

Wages of Full-time Employed in Florida Baccalaureates One Year After Graduation 5th, 25th, 50th, 75th and 95th Percentiles

$\$ 88,400$

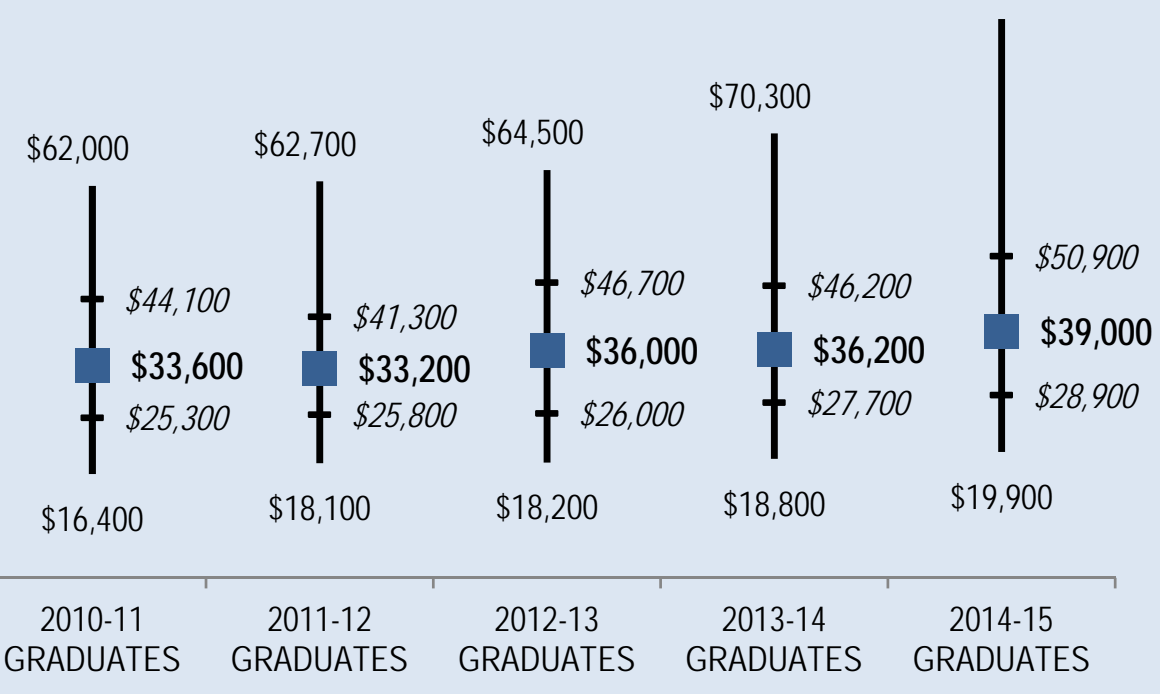

Notes: Percentages are based on the number of recent baccalaureate graduates who are either employed full-time or continuing their education in the U.S. (based on the National Student Clearinghouse data). Full-time employment is based on those who earned more than a full-time (40hrs a week) worker making minimum wage. Due to limitations in the data, the continuing enrollment data includes any enrollment the following year regardless of whether the enrollment was post-baccalaureate or not. Board of Governors staff found xx\% of the total 2014-15 graduating class.

See Table 40 within this report for additional information about this metric.

Notes: Percentages are based on the number of recent baccalaureate araduates Notes: Wage data is based on annualized Unemployment Insurance (UI) wage data for those graduates who earned more than a full-time employee making minimum wage in the fiscal quarter a full year after graduation. This UI wage data does not include individuals who are self- : employed, employed by the military or federal government, or those without a valid social security number. In 2014-15, these data accounted for $\mathrm{xx} \%$ of the total graduating class. This wage data includes graduates who were employed full-time (regardless of their continuing enrollment). Wages are provided for 5th, 25th, 50th, 75th and 95th percentiles. Median wages are identified by bolded values. The interquartile range (shown in italics) represents $50 \%$ of the wage data. Wages rounded to nearest hundreds. 


\section{Key Achievements (2015-16 academic year)}

Include achievements that were received/awarded during summer 2015, fall 2015, and spring 2016.

\section{STUDENT AWARDS/ACHIEVEMENTS}

1. USF Sarasota-Manatee welcomed its first Fulbright scholar, Nefike Gunden, who is a master's degree student in Hospitality and Tourism Management.

2. Accounting student Marina Rambo received the top intern award from JP Morgan Chase in Tampa.

\section{FACULTY AWARDS/ACHIEVEMENTS}

1. Dr. Kathy Black, Professor of Social Work, was named the director of Age-Friendly Sarasota and addressed a committee of the World Health Organization in Geneva, Switzerland, through a presentation about the multi-partner initiative to make Sarasota County friendlier for people across their lifespans.

2. Dr. Sandra Stone, Regional Chancellor, received SRQ magazine's Women in Business Hear Me Roar Award that recognizes women's contributions to education.

\section{PROGRAMAWARDS/ACHIEVEMENTS}

1. USF Sarasota-Manatee opened a Student Veteran Success Center supported by an anonymous $\$ 50,000$ donation.

2. A shortage of audiologists and speech pathologists led the USF Sarasota-Manatee faculty to expand its Communication Sciences \& Disorders program.

\section{RESEARCH AWARDS/ACHIEVEMENTS}

1. Dr. Fawn Ngo, Associate Professor of Criminology, was named editor of a criminologist journal.

2. Dr. Ngo and Dr. Jessica Grosholz, Assistant Professor of Criminology, were asked by Sarasota PD to study its three-year drug crackdown.

3. Dr. Melissa Sloan, Associate Professor of Interdisciplinary Social Sciences, received the USF Women in Leadership and Philanthropy Faculty Research Award. 


\section{Narrative}

\section{Teaching and Learning}

\section{STRENGTHEN QUALTY AND REPUTATION OF ACADEMC PROGRAMS AND UNIVERSTIES}

To better serve the higher education needs of the community, USF Sarasota-Manatee decided to establish a College of Science \& Mathematics (CSM) as part of a realignment of its four colleges to strengthen the quality of academic programs. In addition, plans were made to merge the current College of Arts \& Sciences and College of Education to create a College of Liberal Arts \& Social Sciences (CLASS).

The new College of Liberal Arts \& Social Sciences includes three distinct areas: a School of Education, a Department of Liberal Arts and a Department of Social Sciences. By combining these three areas, USF Sarasota-Manatee has created a college that provides hands-on research and learning opportunities at the undergraduate and graduate levels while allowing for content area preparation which is a foundation for higher education. In addition, the college will include programs that produce workforce-ready students.

USF Sarasota-Manatee is improving its reputation by attracting an ever-higher quality of student. The USF Sarasota-Manatee fall 2015 FTIC cohort showed an improved profile over its fall 2014 FTIC cohort in average SAT scores (2.9\% increase), while average high school grade-point average was stable at 3.78 and the percentage of students in the top $10 \%$ of their high school class represented $20 \%$ of the cohort.

\section{INCREASE DEGREE PRODUCTIVITY AND PROGRAM EFFICIENCY}

The Florida Board of Governors removed USF Sarasota-Manatee's enrollment cap at the lower level, allowing the university to control its own enrollment growth. As a result, USF Sarasota-Manatee is serving a higher percentage of local, traditional students, increasing its lower-level enrollment by $18 \%$ in 2015-16 compared to 2014-15. Overall enrollment also increased year-to-year, headcounts by $7 \%$ and FTE by $11 \%$. Program efficiency is evident by the $77 \%$ of USF Sarasota-Manatee students successful in earning their degrees without excess hours in 2015-16. This is an improvement of $5 \%$ over the previous year's rate of $72 \%$. Additionally, access to distance learning courses increased in 2015-16 as shown by the $18 \%$ increase in FTE generated by DL courses when compared to 2014-15.

USF Sarasota-Manatee students benefit from a new personalized system of advising that includes a "career success map" and teams of professionals to guide them during their education, assist with job choices, and help as they transition toward meaningful new careers. This new career-centric approach to student advising showcases the commitment to higher levels of excellence and career preparedness that is part of the fabric of all institutions throughout the USF System. The changes follow a yearlong evaluation of USF Sarasota-Manatee's advising structure, a review of other advising models in Florida, and consultations with experts about the latest research and innovations in college advising programs. In addition to learning about educational requirements in their prospective fields, students gain access to job training, internships, and advice on how to prepare for interviews. They work closely with advisors to ensure their success in the classroom translates to the workplace. If necessary, students are matched with tutors, financial aid counselors or other advisors to help them succeed in their studies, graduate and find meaningful careers. While working toward degrees, students are equipped with additional, practical 
skills that may also prove useful in the workplace, from technology training and critical thinking to qualitative skills, such as professional communication and workplace collaboration. Some may use this opportunity to explore whether post-graduate education is right for them. Lastly, students will learn about credentials and certifications that may further advance their careers, as well as professional and networking organizations associated with their respective fields.

\section{INCREASE THE NUMBER OF DEGREES AWARDED IN S.T.E.M. AND OTHER PROGRAMS OF STRATEGIC EMPHASIS}

To place emphasis on STEM programs, USF Sarasota-Manatee planned for the establishment of the College of Science \& Mathematics (CSM) as part of a realignment of its four colleges. In partnership with Mote Marine Laboratory, CSM's Biology program, launched in fall of 2014, grew in enrollment from 83 majors to 145 in Fall Semester 2015, a 75\% increase. In Spring Semester 2016, CSM and USF Tampa's College of Engineering partnered to develop a 2+2 pathway for aspiring engineering students.

In addition, the College of Arts \& Sciences and College of Education merged to create a College of Liberal Arts \& Social Sciences (CLASS) to provide greater efficiencies in the delivery of programs of strategic emphasis. 


\section{Narrative}

\section{Scholarship, Research and Innovation}

\section{STRENGTHEN QUALTY AND REPUTATION OF SCHOLARSHIP, RESEARCH AND INNOVATION}

USF Sarasota-Manatee continued the appointment of a research coordinator and hired a grant support specialist to assist in identifying, securing, and administering the scholarly, research and innovation initiatives of the university. These specialists will ensure that the quality and reputation of grant work will be strengthened.

\section{INCREASE RESEARCH AND COMMERCIALIZATION ACTIVTYY}

Additional funding was identified for faculty and staff professional development that can increase USF Sarasota-Manatee's capacity for research and commercialization activity.

Additionally, USF Sarasota-Manatee entered into a consortium with New College of Florida, State College of Florida Manatee-Sarasota, Ringling College of Art and Design, and Eckerd College. This newly formed Consortium of Colleges on the Creative Coast (C4) is pursuing opportunities to collaboratively increase research and commercialization.

\section{INCREASE COLLABORATION AND EXTERNAL SUPPORT FOR RESEARCH ACTIVITY}

USF Sarasota-Manatee's College of Business regularly engages local businesses and non-profits to provide hands-on research and work experience to students. Businesses and non-profits engage the business students by bringing them a real-world problem that they need expertise on. From market studies to the development of business plans, students work side-by-side to help fill the needs of community entities while also developing connections within the community and work that they can include in their undergraduate portfolios. 


\section{Narrative}

\section{Community and Business Engagement}

\section{STRENGTHEN QUALTYY AND REPUTATION OF COMMTMENT TO COMMUNITY AND BUSINESS ENGAGEMENT}

USF Sarasota-Manatee established an Office of Community Engagement to build a campus-wide infrastructure. The Office is charged with cultivating strategic partnerships with government entities, schools, non-profit groups, service clubs, local businesses and community organizations. USF SarasotaManatee plans to submit an application to the Carnegie Foundation for classification as a community engaged university by 2020 .

Also, USF Sarasota-Manatee reconstituted the Institute for Public Policy and Leadership to provide opportunities for the community to interact and exchange ideas with our faculty and students about significant policy and leadership issues.

\section{INCREASE LEVELS OF COMMUNTY AND BUSINESS ENGAGEMENT}

The Florida Legislature named the Center for Partnerships for Arts-Integrated Teaching (PAInT) at USF Sarasota-Manatee as a state-wide Center in Florida. PAInT partners with the Circus Arts Conservatory, a 501(c)3 located in Sarasota, to provide Science, Technology, Engineering, and Math (STEM) education to students in both the Manatee and Sarasota County school systems. This ongoing partnership serves approximately 4,000 students throughout our service area and strengthens STEM education through evidence-based practices that increase student motivation and achievement in the sciences. Also, the Florida Center for PAInT provides professional development for primary school teachers, higher education faculty and students via arts integration activities, curriculum innovation and resource development. We have proactively engaged the local economic development groups and chambers of commerce within the service area. In the coming year faculty plan to meet individually with CEOs of local private businesses to increase PAInT exposure in the community.

\section{INCREASE COMMUNTYY AND BUSINESS WORKFORCE}

USF Sarasota-Manatee believes that leveraging community partnerships is essential in bridging that gap between the classroom and the workforce. The ongoing collaboration between Mote Marine Laboratory, a world-renowned aquarium and research center, and the USF Sarasota-Manatee Biology program focus on the discovery process and a learning environment that engages students outside of the classroom. Students in this internship program gain hands-on opportunities in the planning and implementing of scientific research while working alongside Mote's Ph.D. scientists engaged in active, ongoing marine research. These students also attended, and often reported on work, at research seminars and were able to learn more about opportunities for careers in related fields. This experience enhances the experiential knowledge and career readiness of the students that is essential to future employment.

USF Sarasota-Manatee also believes that building meaningful careers within the local community involves access to a variety of career pathways. While many partnerships involve area schools and businesses, USF Sarasota-Manatee also recently created the "County Career Connections" program 
focused on providing insight into public service opportunities. This program, geared towards students at all levels and majors, highlights the broad spectrum of career and internship opportunities available within local government. This ongoing opportunity allows students to learn more about impactful career options in both Sarasota and Manatee counties. The connection is mutually beneficial in that local governments, expecting a high retirement rate in the near future, are looking to engage and recruit graduates for future employment.

USF Sarasota-Manatee continues to creatively build capacity in the workforce beyond the classroom. The College of Hospitality and Tourism Leadership prepares students for the workforce by incorporating an active learning environment, hands on experience and community engagement. In partnership with the five-star Resort at Longboat Key Club, students have access to a "teaching hotel" that allows them to learn applicable career skills while serving in a public capacity. The Culinary Innovation Lab at Lakewood Ranch continues to serve as a teaching lab that provides a state-of-the-art facility for students to participate in restaurant management and event planning instruction. Through these types of focused, experience-based learning activities, students are learning to manage the complexity of restaurant and hotel operations to gain those critical workforce skills to analyze, execute and lead in the hospitality industry. 


\section{Data Tables}

\section{FINANCIAL RESOURCES}

Table 1A. Education and General Revenues

Table 1B. Education and General Expenditures

Table 1C. Funding per Student FTE

Table 1D. Cost per Degree [Revised]

Table 1E. Other Budget Entities

Table 1F. Voluntary Support of Higher Education

PERSONNEL

Table 2A. Personnel Headcount

\section{ENROLLMENT}

Table 3A. Headcount Enrollment by Student Type [Revised]

Table 3B. Full-time Equivalent (FTE) Enrollment [Revised]

Table 3C. Enrollment by Instructional Method [Revised]

Table 3D. Headcount Enrollment by Military Status and Student Level

Table 3E. University Access Rate: Undergraduate Enrollment with Pell Grant

\section{UNDERGRADUATE EDUCATION}

Table 4A. Baccalaureate Degree Program Changes in AY 2015-2016

Table 4B. Retention Rates

Table 4C. First-Time-in-College (FTIC) Six-Year Graduation Rates (Full-time only)

Table 4D. FTIC Graduation Rates (Full- and Part-time)

Table 4E. AA Transfers Graduation Rates

Table 4F. Other Transfers Graduation Rates

Table 4G. Baccalaureate Degrees Awarded

Table 4H. Baccalaureate Degrees Awarded in Areas of Strategic Emphasis

Table 4I. Baccalaureate Degrees Awarded to Underrepresented Groups

Table 4J. Baccalaureate Degrees Without Excess Credit Hours

Table 4K. Undergraduate Course Offerings

Table 4L. Faculty Teaching Undergraduates

Table 4M. Student/Faculty Ratio

Table 4N. Licensure/Certification Exam: Nursing

Table 4O. Post-Graduation Metrics [Revise?]

\section{GRADUATE EDUCATION}

Table 5A. Graduate Degree Program Changes in AY 2015-2016

Table 5B. Graduate Degrees Awarded

Table 5C. Graduate Degrees Awarded in Areas of Strategic Emphasis

Table 5D. Licensure/Certification Exams: Graduate Programs

\section{RESEARCH \& ECONOMIC DEVELOPMENT}

Table 6A. Research and Development Expenditures

Table 6B. Centers of Excellence 


\section{Section 1 - Financial Resources}

TABLE 1A. University Education and General Revenues

\begin{tabular}{lrrrrr} 
& $\begin{array}{r}2012-13 \\
\text { Actual }\end{array}$ & $\begin{array}{r}2013-14 \\
\text { Actual }\end{array}$ & $\begin{array}{r}2014-15 \\
\text { Actual }\end{array}$ & $\begin{array}{r}2015-16 \\
\text { Actual }\end{array}$ & $\begin{array}{r}2016-17 \\
\text { Estimates }\end{array}$ \\
\hline MAIN OPERATIONS & & & & & \\
\hline Recurring State Funds & $\$ 11,109,190$ & $\$ 12,393,930$ & $\$ 13,874,110$ & $\$ 14,341,394$ & $\$ 15,120,015$ \\
\hline Non-Recurring State Funds & $-\$ 993,867$ & $\$ 882,604$ & $\$ 200,000$ & $\$ 1,528,769$ & $\$ 2,114,773$ \\
\hline Tuition & $\$ 6,082,277$ & $\$ 6,293,560$ & $\$ 6,516,161$ & $\$ 7,404,858$ & $\$ 7,931,495$ \\
\hline Tuition Differential Fee & $\$ 1,397,116$ & $\$ 1,372,963$ & $\$ 1,419,335$ & $\$ 1,540,945$ & $\$ 1,540,300$ \\
\hline Misc. Fees \& Fines & $\$ 61,389$ & $\$ 70,589$ & $\$ 105,180$ & $\$ 128,404$ & $\$ 127,842$ \\
\hline Phosphate/Other TF & $\$ 0$ & $\$ 0$ & $\$ 0$ & $\$ 0$ & $\$ 0$ \\
\hline \multicolumn{1}{c}{ TOTAL } & $\$ 17,656,105$ & $\$ 21,013,646$ & $\$ 22,114,786$ & $\$ 24,944,370$ & $\$ 26,834,425$
\end{tabular}

Recurring State Funds: include general revenue and lottery education \& general (E\&G) appropriations and any administered funds provided by the state, including annual adjustments of risk management insurance premiums for the estimated year. This does not include technical adjustments or transfers made by universities after the appropriation. Please note: 2013-14 revenues include the non-recurring $\$ 300 M$ system budget reduction. Sources: SUS Final Amendment Packages were used for actual years; and, the latest SUS University Conference Report and various workpapers were used for the estimated year. Non-Recurring State Funds: include general revenue and lottery education \& general appropriations and any administered funds provided by the state. This does not include technical adjustments or transfers made by Universities after the appropriation. Source: nonrecurring appropriations section of the annual Allocation Summary and Workpapers that include all other non-recurring budget amendments allocated later in the fiscal year. Note on Performance Funding: the State investment piece of performance funding is reported in the 'Non-Recurring State Funds' and the Institutional investment piece is reported within 'Recurring State Funds'. Tuition: Actual resident \& non-resident tuition revenues collected from students, net of fee waivers. Source: Operating Budget, Report 625 - Schedule I-A. Tuition Differential Fee: Actual tuition differential revenues collected from undergraduate students. Source: Operating Budget, Report 625 - Schedule I-A. Miscellaneous Fees \& Fines: Other revenue collections include items such as application fees, late registration fees, library fines, miscellaneous revenues. This is the total revenue from Report 625 minus tuition and tuition differential fee revenues. This does not include local fees. Source: Operating Budget, Report 625 Schedule I-A. Phosphate/Other Trust Fund: State appropriation for the Florida Industrial and Phosphate Research Institute at the University of South Florida (for history years through 2012-13); beginning 2013-14 the Phosphate Research Trust Fund is appropriated through Florida Polytechnic University. Other Operating Trust Funds. For UF-IFAS and UF-HSC, actual revenues from the Incidental Trust Funds and Operations \& Maintenance Trust Fund are provided by the University of Florida. Source: Final Amendment Package. This data is not adjusted for inflation. 
Section 1 - Financial Resources (continued)

TABLE 1B. University Education and General Expenditures (Dollars in Millions)

\begin{tabular}{lrrrrr} 
& $\mathbf{2 0 1 1 - 1 2 *}$ & $\mathbf{2 0 1 2 - 1 3}$ & $\mathbf{2 0 1 3 - 1 4}$ & $\mathbf{2 0 1 4 - 1 5}$ & 2015-16 \\
\hline $\begin{array}{lrrrr}\text { MAIN OPERATIONS } \\
\text { Instruction/Research }\end{array}$ & $\$ 9,923,115$ & $\$ 11,126,818$ & $\$ 12,313,236$ & $\$ 13,472,997$ & $\$ 15,159,133$ \\
\hline Administration and Support & $\$ 2,196,199$ & $\$ 3,241,243$ & $\$ 3,425,543$ & $\$ 4,496,669$ & $\$ 4,751,681$ \\
\hline PO\&M & $\$ 1,135,491$ & $\$ 1,071,460$ & $\$ 1,127,601$ & $\$ 1,202,826$ & $\$ 1,276,909$ \\
\hline Student Services & $\$ 1,848,275$ & $\$ 1,582,750$ & $\$ 1,614,831$ & $\$ 1,737,160$ & $\$ 1,618,186$ \\
\hline Library/Audio Visual & $\$ 1,071,269$ & $\$ 1,102,445$ & $\$ 1,188,945$ & $\$ 1,181,901$ & $\$ 1,284,224$ \\
\hline Other & $\$ 0$ & $\$ 0$ & $\$ 0$ & $\$ 0$ & $\$ 0$ \\
\hline TOTAL & $\$ 16,174,349$ & $\$ 18,124,716$ & $\$ 19,670,156$ & $\$ 22,091,553$ & $\$ 24,090,133$
\end{tabular}

The table reports actual expenditures from revenues appropriated by the legislature for each fiscal year. The expenditures are classified by Program Component (e.g., Instruction/Research, PO\&M, Administration, etc...) for activities directly related to instruction, research and public service. The table does not include expenditures classified as non-operating expenditures (e.g., to service asset-related debts), and therefore excludes a small portion of the amount appropriated each year by the legislature. Note*: FY 2012-2013 reflects a change in reporting expenditures from prior years due to the new carry-forward reporting requirement as reflected in the 2013-2014 SUS Operating Budget Reports. Since these expenditures will now include carryforward expenditures, these data are no longer comparable to the current-year revenues reported in table 1A, or prior year expenditures in table 1B. This data is not adjusted for inflation.

Instruction \& Research: Includes expenditures for state services related to the instructional delivery system for advanced and professional education. Includes functions such as; all activities related to credit instruction that may be applied toward a postsecondary degree or certificate; non-project research and service performed to maintain professional effectives; individual or project research; academic computing support; academic source or curriculum development. Source: Operating Budget Summary - Expenditures by Program Activity (or Report 645). Administration \& Support Services: Expenditures related to the executive direction and leadership for university operations and those internal management services which assist and support the delivery of academic programs. Source: Operating Budget Summary - Expenditures by Program Activity (or Report 645). PO\&M: Plant Operations \& Maintenance expenditures related to the cleaning and maintenance of existing grounds, the providing of utility services, and the planning and design of future plant expansion and modification. Student Services: Includes resources related to physical, psychological, and social well-being of the student. Includes student service administration, social and cultural development, counseling and career guidance, financial aid, and student admissions and records. Other: includes Institutes and Research Centers, Radio/TV, Museums and Galleries, Intercollegiate Athletics, Academic Infrastructure Support Organizations. Source: Operating Budget Summary - Expenditures by Program Activity (or Report 645). 


\section{Section 1 - Financial Resources (continued)}

\section{TABLE 1C. Funding per Full-Time Equivalent (FTE) Student}

\begin{tabular}{|c|c|c|c|c|c|}
\hline & 2011-12 & 2012-13 & 2013-14 & 2014-15 & 2015-16 \\
\hline State Appropriation (GR \& Lottery) & $\$ 7,110$ & $\$ 6,359$ & $\$ 8,546$ & $\$ 8,783$ & $\$ 8,811$ \\
\hline Tuition \& Fees (State-funded Aid) & $\$ 479$ & $\$ 381$ & $\$ 526$ & $\$ 510$ & $\$ 473$ \\
\hline Tuition \& Fees (from Student) & $\$ 4,063$ & $\$ 4,375$ & $\$ 4,637$ & $\$ 4,687$ & $\$ 4,565$ \\
\hline Other Trust Funds & $\$ 0$ & $\$ 0$ & $\$ 0$ & $\$ 0$ & $\$ 0$ \\
\hline TOTAL & $\$ 11,652$ & $\$ 11,115$ & $\$ 13,708$ & $\$ 13,981$ & $\$ 13,850$ \\
\hline
\end{tabular}

Notes: Data provided by USF staff instead of BOG staff queries of SUDS due to the FTE calculations required. State Appropriations includes General Revenues and Lottery funds that are directly appropriated to the university as reported in Final Amendment Package. This does not include appropriations for special units (e.g., IFAS, Health Science Centers, and Medical Schools). Tuition and Fee revenues include tuition and tuition differential fee and E\&G fees (e.g., application, late registration, and library fees/fines) as reported on the from the Operating Budget 625 reports. Other local fees that do not support E\&G activities are not included here (see Board of Governors Regulation 7.003). To more accurately report the full contribution from the State, this table reports the state-funded financial aid separately from the tuition and fee payments universities receive from students (which may include federal financial aid dollars). The state-funded gift aid includes grants and scholarships as reported by universities to Board during the academic year in the State University Database (SUDS). Other Trust funds (e.g., Federal Stimulus for 2009-10 and 2010-11 only) as reported in Final Amendment Package. Fulltime Equivalent enrollment is based on actual FTE, not funded FTE; and, does not include Health-Science Center funds or FTE. This data is based on the standard IPEDS definition of FTE, equal to 30 credit hours for undergraduates and 24 for graduates. This data is not adjusted for inflation. Data provided by USF staff.

\section{TABLE 1D. Cost per Bachelor's Degree}

2008-12

Cost to the Institution
2009-13

REPORTED AT THE USF-SYSTEM LEVEL

\section{[NEW]}

Cost to the Student: Net Tuition \& Fees per 120 Credit Hours
2011-12

2012-13

2013-14

2014-15

2015-16

Notes: Cost to the Institution reports the Full expenditures include direct instructional, research and public service expenditures and the undergraduate portion of indirect expenditures (e.g., academic administration, academic advising, student services, libraries, university support, and Plant Operations and Maintenance). For each year, the full expenditures were divided by undergraduate fundable student credit hours to calculate the full expenditures per credit hour, and then multiplied by 30 credit hours to represent the annual undergraduate expenditures. The annual undergraduate expenditures for each of the four years was summed to provide an average undergraduate expenditures per (120 credit) degree. Source: State University Database System (SUDS), Expenditure Analysis: Report IV. Net Tuition \& Fees per 120 Credit Hours represents the average tuition and fees paid, after considering gift aid (e.g., grants, scholarships, waivers), by resident undergraduate FTICs who graduate from a program that requires 120 credit hours. This data includes an approximation for the cost of books. For more information about how this metric is calculated please see the methodology document at the Board's webpage, at: http://www.flbog.edu/about/budget/performance funding.php. This data is not adjusted for inflation. 


\title{
Section 1 - Financial Resources (continued)
}

TABLE 1E. University Other Budget Entities (Dollars in Millions)

2011-12 2012-13 2013-14

2014-15

2015-16

Auxiliary Enterprises

Revenues

Expenditures

$\$ 1,888,702$

$\$ 1,859,520$

$\$ 1,989,594$

$\$ 2,272,898$

$\$ 2,590,207$

$\$ 1,452,865$

$\$ 1,144,646$

$\$ 2,117,132$

$\$ 2,106,864$

$\$ 2,279,120$

Contracts \& Grants

\section{Revenues}

Expenditures

Local Funds

Revenues
Expenditures
aculty Practice Plans
Revenues

Revenues

Expenditures

$\$ 207,283$

$$
\$ 300,044
$$

$\$ 38,107$

$\$ 152,204$

$-\$ 47,820$
$\$ 246,905$

$\$ 168,148$

$\$ 461,764$

$\$ 231,685$

$\$ 491,249$

$\begin{array}{rr}\$ 1,149,499 & \$ 1,149,481 \\ \$ 576,226 & \$ 1,060,747\end{array}$

$\$ 1,129,900$
$\$ 909,324$

$\$ 1,204,897$
$\$ 711,547$

$\$ 1,334,634$

$\$ 1,026,810$

$\begin{array}{ll}\$ 0 & \$ 0 \\ \$ 0 & \$ 0\end{array}$

$\$ 0$
$\$ 0$

$\$ 0$
$\$ 0$

$\$ 0$
$\$ 0$

Notes: Revenues do not include transfers. Expenditures do not include non-operating expenditures. Auxiliary Enterprises are self-supported through fees, payments and charges. Examples include housing, food services, bookstores, parking services, health centers. Contract \& Grants resources are received from federal, state or private sources for the purposes of conducting research and public service activities. Local Funds are associated with student activity (supported by the student activity fee), student financial aid, concessions, intercollegiate athletics, technology fee, green fee, and student life \& services fee. Faculty Practice Plan revenues/receipts are funds generated from faculty practice plan activities. Faculty Practice Plan expenditures include all expenditures relating to the faculty practice plans, including transfers between other funds and/or entities. This may result in double counting in information presented within the annual report. Source: Operating Budget, Report 615. This data is not adjusted for inflation.

\section{TABLE 1F. Voluntary Support of Higher Education}

$$
\text { 2011-12 }
$$

2012-13

2013-14

2014-15

2015-16

\author{
Endowment Value \\ (\$1000s) \\ Gifts Received \\ (\$1000s) \\ Percentage of \\ Alumni Donors
}

REPORTED AT THE USF-SYSTEM LEVEL

Notes: Endowment value at the end of the fiscal year, as reported in the annual NACUBO Endowment Study. Gifts Received as reported in the Council for Aid to Education's Voluntary Support of Education (VSE) survey in the section entitled "Gift Income Summary," this is the sum of the present value of all gifts (including outright and deferred gifts) received for any purpose and from all sources during the fiscal year, excluding pledges and bequests. (There's a deferred gift calculator at www.cae.org/vse.) The present value of non-cash gifts is defined as the tax deduction to the donor as allowed by the IRS. Percentage of Alumni Donors as reported in the Council for Aid to Education's Voluntary Support of Education (VSE) survey in the section entitled "Additional Details," this is the number of alumni donors divided by the total number of alumni, as of the end of the fiscal year. "Alumni," as defined in this survey, include those holding a degree from the institution as well as those who attended the institution but did not earn a degree. This data is not adjusted for inflation. 


\section{Section 2 - Personnel}

TABLE 2A. Personnel Headcount (in Fall term only)

\begin{tabular}{lccccc} 
& $\mathbf{2 0 1 1}$ & $\mathbf{2 0 1 2}$ & $\mathbf{2 0 1 3}$ & $\mathbf{2 0 1 4}$ & $\mathbf{2 0 1 5}$ \\
\hline Full-time Employees & 13 & 14 & 17 & 23 & 23 \\
\hline Tenured Faculty & 24 & 21 & 14 & 14 & 14 \\
Tenure-track Faculty & 20 & 22 & 39 & 43 & 45 \\
Non-Tenure Track Faculty & 0 & 0 & 0 & 0 & 0 \\
Instructors Without Faculty Status & 0 & 0 & 0 & 0 & 0 \\
Graduate Assistants/Associates & 95 & 93 & 102 & 112 & 117 \\
Non-Instructional Employees & 152 & $\mathbf{1 5 0}$ & $\mathbf{1 7 2}$ & $\mathbf{1 9 2}$ & $\mathbf{1 9 9}$
\end{tabular}

\section{Part-time Employees}

\begin{tabular}{lccccc} 
Tenured Faculty & 1 & 0 & 0 & 0 & 0 \\
Tenure-track Faculty & 0 & 0 & 0 & 0 & 0 \\
Non-Tenure Track Faculty & 75 & 64 & 74 & 57 & 61 \\
Instructors Without Faculty Status & 0 & 0 & 0 & 0 & 0 \\
Graduate Assistants/Associates & 5 & 7 & 4 & 5 & 12 \\
Non-Instructional Employees & 0 & 0 & 0 & 0 & 0 \\
\hline PART-TIME SUBTOTAL & $\mathbf{8 1}$ & $\mathbf{7 1}$ & $\mathbf{7 8}$ & $\mathbf{6 2}$ & $\mathbf{7 3}$ \\
\hline \multicolumn{1}{c}{ TOTAL } & $\mathbf{2 3 3}$ & $\mathbf{2 2 1}$ & $\mathbf{2 5 0}$ & $\mathbf{2 5 4}$ & $\mathbf{2 7 2}$
\end{tabular}

Note: This table is based on the annual IPEDS Human Resources Survey, and provides full- and part-ime medical and non-medical staff by faculty status and primary function/occupational activity. Tenured and Tenure-Track Faculty include those categorized within instruction, research, or public service. Non-Tenure Track Faculty includes adjunct faculty (on annual and less than annual contracts) and faculty on multi-year contracts categorized within instruction, research, or public service. Instructors Without Faculty Status includes postdoctoral research associates, and individuals hired as a staff member primarily to do research on a 3-year contract without tenure eligibility categorized within instruction, research, or public service. Non-Instructional Employees includes all executive, administrative and managerial positions regardless of faculty status; as well as, other support and service positions regardless of faculty status. Note: The universities vary on how they classify adjuncts (some include them as non-tenure track faculty while others do not consider them faculty and report them as instructors without faculty status) and part-time non-instructional employees. Data provided by USF staff. 


\section{Section 3 - Enrollment}

TABLE 3A. Headcount Enrollment by Student Type and Level [REVISED]

\begin{tabular}{lccccc} 
& Fall 2011 & Fall 2012 & Fall 2013 & Fall 2014 & Fall 2015 \\
\hline TOTAL & 1,919 & 1,952 & 1,887 & 1,917 & 2,044
\end{tabular}

\begin{tabular}{lccccc} 
UNDERGRADUATE & \multicolumn{7}{c}{} & & & \\
\cline { 1 - 5 } FTIC (Regular Admit) & 27 & 30 & 109 & 195 & 268 \\
FTIC (Profile Admit) & 0 & 0 & 0 & 1 & 3 \\
FCS AA Transfers & 943 & 918 & 826 & 789 & 781 \\
Other AA Transfers & 174 & 181 & 169 & 155 & 159 \\
Post-Baccalaureates & 0 & 0 & 0 & 152 & 127 \\
Other Undergraduates & 461 & 583 & 567 & 400 & 419 \\
\hline Subtotal & 1,605 & 1,712 & 1,671 & 1,692 & 1,757
\end{tabular}

\section{GRADUATE}

\begin{tabular}{lccccc}
\hline Master's & 159 & 140 & 128 & 120 & 174 \\
Research Doctoral & 0 & 0 & 0 & 0 & 0 \\
Professional Doctoral & 0 & 0 & 0 & 0 & 0 \\
\hline Dentistry & 0 & 0 & 0 & 0 & 0 \\
Law & 0 & 0 & 0 & 0 & 0 \\
Medicine & 0 & 0 & 0 & 0 & 0 \\
Nursing Practice & 0 & 0 & 0 & 0 & 0 \\
Pharmacy & 0 & 0 & 0 & 0 & 0 \\
Physical Therapist & 0 & 0 & 0 & 0 & 0 \\
Veterinary Medicine & 0 & 0 & 0 & 0 & 0 \\
Other & 0 & 0 & 0 & 0 & 0 \\
\hline Subtotal & 159 & 140 & $\mathbf{1 2 8}$ & $\mathbf{1 2 0}$ & $\mathbf{1 7 4}$
\end{tabular}

UNCLASSIFIED

\begin{tabular}{lccccc}
\hline HS Dual Enrolled & 0 & 0 & 0 & 0 & 0 \\
Other & 155 & 100 & 88 & 105 & 113 \\
\hline Subtotal & 155 & 100 & $\mathbf{8 8}$ & 105 & $\mathbf{1 1 3}$
\end{tabular}

Note: This table reports the number of students enrolled at the university by student type categories. The student type for undergraduates is based on the Type of Student at Time of Most Recent Admission. The student type for graduates is based on the degree that is sought and the student CIP code. Unclassified refers to a student who has not yet been formally admitted into a degree program but is enrolled. The methodology for this table was revised at the June 2017 Data Administrator Workshop. The change improves how post-baccalaureate undergraduate students are counted. 


\section{Section 3 - Enrollment (continued)}

\section{TABLE 3B. Full-Time Equivalent (FTE) Enrollment [REVISED]}

\begin{tabular}{lccccc} 
& $\mathbf{2 0 1 1 - 1 2}$ & $\mathbf{2 0 1 2 - 1 3}$ & $\mathbf{2 0 1 3 - 1 4}$ & $\mathbf{2 0 1 4 - 1 5}$ & $\mathbf{2 0 1 5 - 1 6}$ \\
\hline RESIDENT FUNDABLE & & & & & \\
\hline LOWER & 143 & 178 & 274 & 339 & 393 \\
UPPER & 1,281 & 1,244 & 1,096 & 1,074 & 1,161 \\
MASTERS (GRAD I) & 142 & 125 & 127 & 118 & 145 \\
DOCTORAL (GRAD II) & 1 & 0 & 0 & 0 & 0 \\
TOTAL & $\mathbf{1 , 5 6 7}$ & $\mathbf{1 , 5 4 7}$ & $\mathbf{1 , 4 9 7}$ & $\mathbf{1 , 5 3 1}$ & $\mathbf{1 , 7 0 0}$ \\
NON-RESIDENT FUNDABLE & & & & & \\
\hline LOWER & 4 & 11 & 16 & 22 & 31 \\
UPPER & 27 & 26 & 34 & 41 & 54 \\
MASTERS (GRAD I) & 7 & 7 & 7 & 7 & 15 \\
DOCTORAL (GRAD II) & 0 & 0 & 0 & 0 & 0 \\
TOTAL & $\mathbf{3 9}$ & $\mathbf{4 4}$ & $\mathbf{5 7}$ & $\mathbf{7 1}$ & $\mathbf{1 0 1}$
\end{tabular}

TOTAL FUNDABLE

$\begin{array}{lccccc}\text { LOWER } & 147 & 189 & 290 & 361 & 425 \\ \text { UPPER } & 1,308 & 1,269 & 1,130 & 1,116 & 1,216 \\ \text { MASTERS (GRAD I) } & 149 & 132 & 134 & 125 & 160 \\ \text { DOCTORAL (GRAD II) } & 2 & 0 & 0 & 1 & 1 \\ \text { TOTAL } & \mathbf{1 , 6 0 6} & \mathbf{1 , 5 9 1} & \mathbf{1 , 5 5 4} & \mathbf{1 , 6 0 2} & \mathbf{1 , 8 0 1}\end{array}$

TOTAL NON-FUNDABLE

$\begin{array}{lccccc}\text { LOWER } & 3 & 3 & 6 & 4 & 6 \\ \text { UPPER } & 20 & 19 & 21 & 39 & 27 \\ \text { MASTERS (GRAD I) } & 1 & 1 & 1 & 2 & 2 \\ \text { DOCTORAL (GRAD II) } & 0 & 0 & 0 & 0 & 0 \\ \text { TOTAL } & \mathbf{2 4} & \mathbf{2 4} & \mathbf{2 7} & \mathbf{4 5} & \mathbf{3 5}\end{array}$

TOTAL

$\begin{array}{lccccc}\text { LOWER } & 150 & 192 & 296 & 365 & 431 \\ \text { UPPER } & 1,329 & 1,288 & 1,151 & 1,155 & 1,243 \\ \text { MASTERS (GRAD I) } & 150 & 134 & 134 & 127 & 162 \\ \text { DOCTORAL (GRAD II) } & 2 & 0 & 0 & 1 & 1 \\ \text { TOTAL } & \mathbf{1 , 6 3 0} & \mathbf{1 , 6 1 5} & \mathbf{1 , 5 8 1} & \mathbf{1 , 6 4 7} & \mathbf{1 , 8 3 6}\end{array}$

Notes: Data provided by USF staff instead of BOG staff queries of SUDS. Full-time Equivalent (FTE) student is a measure of instructional activity that is based on the number of credit hours that students enroll by course level. Note about Revision: This table now reports FTE based on the US definition, which divides undergraduate credit hours by 30 and graduate credit hours by 24 . Courses are reported by Universities to the Board of Governors in the Student Instruction File (SIF) as either fundable or non-fundable. In general, student credit hours are considered 'fundable' if they can be applied to a degree, and the associated faculty was paid from State appropriations. Totals are actual and may not equal the sum of reported student levels due to rounding of student level FTE. Data provided by USF staff. 
Section 3 - Enrollment (continued)

TABLE 3C. Full-Time Equivalent (FTE) Enrollment by Instructional Method [REVISED] 2011-12 2012-13 2013-14 2014-15 2015-16

TRADITIONAL

$\begin{array}{lccccc}\text { LOWER } & 86 & 88 & 174 & 230 & 267 \\ \text { UPPER } & 678 & 621 & 489 & 513 & 520 \\ \text { MASTERS (GRAD I) } & 117 & 98 & 97 & 78 & 110 \\ \text { DOCTORAL (GRAD II) } & 1 & 0 & 0 & 0 & 0 \\ \text { TOTAL } & \mathbf{8 8 2} & \mathbf{8 0 8} & \mathbf{7 6 0} & \mathbf{8 2 1} & \mathbf{8 9 8}\end{array}$

HYBRID

$\begin{array}{lccccc}\text { LOWER } & 4 & 10 & 11 & 11 & 0 \\ \text { UPPER } & 42 & 36 & 51 & 22 & 8 \\ \text { MASTERS (GRAD I) } & 5 & 5 & 6 & 6 & 2 \\ \text { DOCTORAL (GRAD II) } & 0 & 0 & 0 & 0 & 0 \\ \text { TOTAL } & 51 & 51 & 67 & \mathbf{3 9} & \mathbf{1 0}\end{array}$

DISTANCE LEARNING

\begin{tabular}{lccccc} 
LOWER & 60 & 94 & 110 & 124 & 164 \\
UPPER & 609 & 632 & 611 & 619 & 714 \\
MASTERS (GRAD I) & 28 & 30 & 31 & 44 & 50 \\
DOCTORAL (GRAD II) & 1 & & 0 & 1 & 1 \\
TOTAL & 697 & 756 & 753 & 787 & $\mathbf{9 2 8}$ \\
TOTAL & & & & & \\
\hline LOWER & 150 & 192 & 296 & 365 & 431 \\
UPPER & 1,329 & 1,288 & 1,151 & 1,155 & 1,243 \\
MASTERS (GRAD I) & 150 & 134 & 134 & 127 & 162 \\
DOCTORAL (GRAD II) & 2 & 0 & 0 & 1 & 1 \\
TOTAL & 1,630 & 1,615 & 1,581 & 1,647 & $\mathbf{1 , 8 3 6}$
\end{tabular}

Note: Data provided by USF staff instead of BOG staff queries of SUDS. Full-time Equivalent (FTE) student is a measure of instructional effort (and student activity) that is based on the number of credit hours that students enroll by course level. Note about Revision: FTE is now based on the standard national definition, which divides undergraduate credit hours by 30 and graduate credit hours by 24 . This data includes all instructional activity regardless of funding category.

Distance Learning is a course in which at least 80 percent of the direct instruction of the course is delivered using some form of technology when the student and instructor are separated by time or space, or both (per 1009.24(17), F.S.). In the future, this table will be able to split these FTE into two subgroups: $100 \%$ DL and $80-99 \%$ DL. Hybrid is a course where $50 \%$ to $79 \%$ of the instruction is delivered using some form of technology, when the student and instructor are separated by time or space, or both (per SUDS data element 2052). Traditional refers to instruction that occurs primarily in the classroom. This designation is defined as less than $50 \%$ of the direct instruction of the course is delivered using some form of technology when the student and instructor are separated by time, space or both. This designation can include activities that do not occur in a classroom (ie, labs, internships, practica, clinicals, labs, etc) - per SUDS data element 2052. Totals are actual and may not equal sum of reported student levels due to rounding of student level FTE. Data provided by USF staff. 


\section{Section 3 - Enrollment (continued)}

TABLE 3D. Headcount Enrollment by Military Status and Student Level

Fall $2011 \quad$ Fall $2012 \quad$ Fall $2013 \quad$ Fall $2014 \quad$ Fall 2015

\begin{tabular}{lccccc}
\hline MILITARY & \multicolumn{1}{c}{ ( } & & & \\
\hline Unclassified & 4 & 1 & 0 & 1 & 0 \\
Undergraduate & 43 & 51 & 69 & 75 & 66 \\
Master's (GRAD 1) & 5 & 8 & 6 & 3 & 4 \\
Doctoral (GRAD 2) & 0 & 0 & 0 & 0 & 0 \\
Subtotal & 52 & 60 & 75 & 79 & 70 \\
DEPENDENTS & & & & & \\
\hline Unclassified & 0 & 0 & 0 & 0 & 0 \\
Undergraduate & 10 & 14 & 9 & 7 & 11 \\
Master's (GRAD 1) & 0 & 1 & 1 & 0 & 0 \\
Doctoral (GRAD 2) & 0 & 0 & 0 & 0 & 0 \\
Subtotal & 10 & 15 & 10 & 7 & 11 \\
NON-MILITARY & & & & & \\
\hline Unclassified & 151 & 99 & 88 & 104 & 113 \\
Undergraduate & 1,552 & 1,647 & 1,593 & 1,610 & 1,680 \\
Master's (GRAD 1) & 154 & 131 & 121 & 117 & 170 \\
Doctoral (GRAD 2) & 0 & 0 & 0 & 0 & 0 \\
Subtotal & 1,857 & $\mathbf{1 , 8 7 7}$ & $\mathbf{1 , 8 0 2}$ & $\mathbf{1 , 8 3 1}$ & $\mathbf{1 , 9 6 3}$ \\
\hline TOTAL & $\mathbf{1 , 9 1 9}$ & $\mathbf{1 , 9 5 2}$ & $\mathbf{1 , 8 8 7}$ & $\mathbf{1 , 9 1 7}$ & $\mathbf{2 , 0 4 4}$ \\
\hline
\end{tabular}

Note: This table provides trend data on the number of students enrolled based on their military status. Military includes students who were classified as Active Duty, Veterans, National Guard, or Reservist.. Eligible Dependents includes students who were classified as eligible dependents (dependents who received veteran's benefits). Non-Military includes all other students.

\section{TABLE 3E. University Access Rate: Undergraduate Enrollment with Pell Grant}

\begin{tabular}{lccccc} 
& Fall 2011 & Fall 2012 & Fall 2013 & Fall 2014 & Fall 2015 \\
\hline Pell Grant Recipients & 794 & 711 & 679 & 693 & 714 \\
\hline Percent with Pell Grant & $49.91 \%$ & $41.65 \%$ & $40.73 \%$ & $45.23 \%$ & $44.43 \%$
\end{tabular}

Note: This table reports the University's Access Rate, which is a measure of the percentage of undergraduate students who have received a federal Pell grant award during a given Fall term. The top row reports the number of students who received a Pell Grant award. The bottom row provides the percentage of eligible students that received a Pell Grant award. This metric is included in the Board of Governors Performance Based Funding Model - for more information see: http://www.flbog.edu/about/budget/performance funding.php. Data provided by USF staff. 


\section{Section 4 - Undergraduate Education}

\section{TABLE 4A. Baccalaureate Degree Program Changes in AY 2015-16}

\begin{tabular}{|c|c|c|c|c|c|}
\hline Title of Program & $\begin{array}{l}\text { Six-digit } \\
\text { CIP } \\
\text { Code }\end{array}$ & $\begin{array}{c}\text { Degree } \\
\text { Level }\end{array}$ & $\begin{array}{l}\text { Date of } \\
\text { UBOT } \\
\text { Action }\end{array}$ & $\begin{array}{l}\text { Starting } \\
\text { or Ending } \\
\text { Term }\end{array}$ & Comments \\
\hline \multicolumn{6}{|l|}{ New Programs } \\
\hline \multicolumn{6}{|l|}{ None } \\
\hline \multicolumn{6}{|l|}{ Terminated Programs } \\
\hline Exceptional Student Education & 13.1001 & Bachelors & 6/4/2015 & 2015 FALL & \\
\hline \multicolumn{6}{|c|}{ Programs Suspended for New Enrollments } \\
\hline None & & & & & \\
\hline \multicolumn{6}{|c|}{ New Programs Considered By University But Not Approved } \\
\hline None & & & & & \\
\hline
\end{tabular}

Note: This table does not include new majors or concentrations added under an existing degree program CIP Code. This table reports the new and terminated program changes based on Board action dates between May 5, 2015 and May 4, 2016.

New Programs are proposed new degree programs that have been completely through the approval process at the university and, if appropriate, the Board of Governors. Does not include new majors or concentrations added under an existing degree program CIP Code.

Terminated Programs are degree programs for which the entire CIP Code has been terminated and removed from the university's inventory of degree programs. Does not include majors or concentrations terminated under an existing degree program CIP Code if the code is to remain active on the academic degree inventory.

Programs Suspended for New Enrollments are degree programs for which enrollments have been temporarily suspended for the entire CIP Code, but the program CIP Code has not been terminated. Does not include majors or concentrations suspended under an existing degree program CIP Code if the code is to remain active on the academic degree inventory and new enrollments in any active major will be reported. Programs included in this list may have been suspended for new enrollments sometime in the past and have continued to be suspended at least one term of this academic year.

New Programs Considered by University But Not Approved includes any programs considered by the university board of trustees, or any committee of the board, but not approved for implementation. Also include any programs that were returned prior to board consideration by the university administration for additional development, significant revisions, or re-conceptualization; regardless of whether the proposal was eventually taken to the university board for approval. Count the returns once per program, not multiple times the proposal was returned for revisions, unless there is a total re-conceptualization that brings forward a substantially different program in a different CIP Code. 


\section{Section 4 - Undergraduate Education (continued)}

\section{TABLE 4B. Full-time, First-Time-in-College (FTIC) Retention Rates}

\section{Retained in the Second Fall Term at Same University}

2011-12

2012-13

2013-14

2014-15

2015-16

\section{Cohort Size}

Retained at USF-Sar.-Man.

.

.

.

83

89 87

$$
\text { with Any GPA }
$$

with GPA 2.0 or higher

$72 \%$

$69.88 \%$

$79 \%$

$78.65 \%$
$85 \%$

$74.71 \%$

\section{Retained within USF-System}

$$
\text { with Any GPA }
$$

with GPA 2.0 or higher
$81 \%$

$77.11 \%$
$87 \%$

$86.67 \%$
91\%

$80.46 \%$

Notes: Data reflected are from BOG staff queries of SUDS, yet minor reconciliation of cohort sizes are still pending. Cohorts are based on undergraduate students who enter the institution in the Fall term (or Summer term and continue into the Fall term). Percent Retained with Any GPA is based on student enrollment in the Fall term following their first year. Percent Retained with GPA Above $\mathbf{2 . 0}$ is based on student enrollment in the Fall term following their first years for those students with a GPA of 2.0 or higher at the end of their first year (Fall, Spring, Summer). The most recent year of Retention data is based on preliminary data (SIFP file) that is comparable to the final data (SIF file) but may be revised in the following years based on changes in student cohorts. The 'Percent Retained with GPA Above 2.0' is also known as the 'Academic Progress Rate' and is included in the Board of Governors Performance Based Funding Model - for more information see:

http://www.flbog.edu/about/budget/performance funding.php.

\section{TABLE 4C. Full-time, First-Time-in-College (FTIC) Six-Year Graduation Rates}

Term of Entry
Cohort Size
\% Graduated
\% Still Enrolled
USF-SM began admitting FTICs in Fall 2013.
\% Success Rate
Note-12




\section{Section 4 - Undergraduate Education (continued)}

\section{TABLE 4E. Graduation Rates for AA Transfer Students from Florida College System}

\begin{tabular}{lccccc} 
Two - Year Rates & $\mathbf{2 0 1 0 - 1 2}$ & $\mathbf{2 0 1 1 - 1 3}$ & $\mathbf{2 0 1 2 - 1 4}$ & $\mathbf{2 0 1 3 - 1 5}$ & $\mathbf{2 0 1 4 - 1 6}$ \\
\hline Cohort Size & 278 & 253 & 243 & 222 & 228 \\
Same University & $\mathbf{2 9 \%}$ & $\mathbf{3 4 \%}$ & $\mathbf{2 5 \%}$ & $\mathbf{2 2 \%}$ & $\mathbf{2 0 \%}$
\end{tabular}

\begin{tabular}{lccccc} 
Four - Year Rates & $\mathbf{2 0 0 8 - 1 2}$ & $\mathbf{2 0 0 9 - 1 3}$ & $\mathbf{2 0 1 0 - 1 4}$ & $\mathbf{2 0 1 1 - 1 5}$ & $\mathbf{2 0 1 2 - 1 6}$ \\
\hline Cohort Size & 272 & 223 & 278 & 253 & 243 \\
Same University & $\mathbf{5 3 \%}$ & $\mathbf{6 5 \%}$ & $\mathbf{6 3 \%}$ & $\mathbf{6 0 \%}$ & $\mathbf{5 6 \%}$
\end{tabular}

Notes: Data reflected are from BOG staff queries of SUDS, yet minor reconciliation of cohort sizes are still pending. AA Transfer cohort is defined as undergraduates entering in the fall term (or summer continuing to fall) and having earned an AA degree from an institution in the Florida College System. For comparability with FTIC cohorts, AA Transfer cohorts are based on undergraduate students who enter the institution in the Fall term (or Summer term and continue into the Fall term) and graduate from the same institution within two or four years.

TABLE 4F. Graduation Rates for Other Transfer Students

\begin{tabular}{lccccc}
$\mathbf{5}-$ Year Rates & $\mathbf{2 0 0 7 - 1 2}$ & $\mathbf{2 0 0 8 - 1 3}$ & $\mathbf{2 0 0 9 - 1 4}$ & $\mathbf{2 0 1 0 - 1 5}$ & $\mathbf{2 0 1 1 - 1 6}$ \\
\hline Cohort Size & 191 & 149 & 191 & 199 & 198 \\
Same University & $\mathbf{5 4 \%}$ & $\mathbf{5 6 \%}$ & $\mathbf{6 1 \%}$ & $\mathbf{6 0 \%}$ & $\mathbf{5 6 \%}$
\end{tabular}

Notes: Data reflected are from BOG staff queries of SUDS, yet minor reconciliation of cohort sizes are still pending. Other Transfer Students includes undergraduate students that transfer into a university who are not FTICs or AA Transfers. Cohorts are based on undergraduate students who enter the institution in the Fall term (or Summer term and continue into the Fall term) and graduate from the same institution within five years. 


\section{Section 4 - Undergraduate Education (continued)}

TABLE 4G. Baccalaureate Degrees Awarded

\begin{tabular}{lccccc} 
& $\mathbf{2 0 1 1 - 1 2}$ & $\mathbf{2 0 1 2 - 1 3}$ & $\mathbf{2 0 1 3 - 1 4}$ & $\mathbf{2 0 1 4 - 1 5}$ & $\mathbf{2 0 1 5 - 1 6}$ \\
\hline First Majors & 514 & 556 & 490 & 474 & 464 \\
Second Majors & 7 & 5 & 2 & 3 & 1 \\
\hline TOTAL & 521 & 561 & 492 & 477 & 465
\end{tabular}

Note: This table reports the number of degrees awarded by academic year. First Majors include the most common scenario of one student earning one degree in one Classification of Instructional Programs (CIP) code. In those cases where a student earns a baccalaureate degree under two different degree CIPS, a distinction is made between "dual degrees" and "dual majors." Also included in first majors are "dual degrees" which are counted as separate degrees (e.g., counted twice). In these cases, both degree CIPs receive a "degree fraction" of 1.0. Second Majors include all dual/second majors (e.g., degree CIP receive a degree fraction that is less than 1 ). The calculation of degree fractions is made according to each institution's criteria. The calculation for the number of second majors rounds each degree CIP's fraction of a degree up to 1 and then sums the total. Second Majors are typically used when providing degree information by discipline/CIP, to better conveys the number of graduates who have specific skill sets associated with each discipline.

\section{TABLE 4H. Baccalaureate Degrees in Programs of Strategic Emphasis (PSE)} [Includes Second Majors]

2011-12

STEM

HEALTH

GLOBALIZATION

EDUCATION

GAP ANALYSIS

SUBTOTAL

PSE PERCENT OF TOTAL
14

13

0

63

89
$34.36 \%$
179
2012-13

2013-14
2014-15

35

54

0

28

79

59

167

167

$33.94 \%$

196

$39.75 \%$

223

2015-16

31

39

0

30

72

172

Notes: This is a count of baccalaureate majors for specific Programs of Strategic Emphasis, as determined by the Board of Governors staff with consultation with business and industry groups and input from universities. This is a count of baccalaureate degrees awarded within specific Programs of Strategic Emphasis, as determined by the Board of Governors staff with consultation with business and industry groups and input from universities - for more information see: http://www.flbog.edu/pressroom/strategic emphasis/. The Board of Governors revised the list of Programs of Strategic Emphasis in November 2013, and the new categories were applied to the historical degrees. A student who has multiple majors in the subset of targeted Classification of Instruction Program codes will be counted twice (i.e., double-majors are included). 


\section{Section 4 - Undergraduate Education (continued)}

\section{TABLE 4I. Baccalaureate Degrees Awarded to Underrepresented Groups}

2011-12

2012-13

2013-14

2014-15

2015-16

Non-Hispanic Black

$\begin{array}{lccccc}\text { Number of Degrees } & 24 & 35 & 16 & 36 & 36 \\ \text { Percentage of Degrees } & 5 \% & 6 \% & 3 \% & 8 \% & 8 \%\end{array}$

Hispanic

Number of Degrees

58

65

59

71

58

Percentage of Degrees

$12 \%$

$12 \%$

$12 \%$

$16 \%$

$13 \%$

\section{Pell-Grant Recipients}

$\begin{array}{lccccc}\text { Number of Degrees } & 280 & 296 & 259 & 237 & 242 \\ \text { Percentage of Degrees } & 56 \% & 54 \% & 54 \% & 52 \% & 54 \%\end{array}$

Note: Non-Hispanic Black and Hispanic do not include students classified as Non-Resident Alien or students with a missing race code. Students who earn two distinct degrees in the same term are counted twice - whether their degrees are from the same six-digit CIP code or different CIP codes. Students who earn only one degree are counted once - even if they completed multiple majors or tracks. Percentage of Degrees is based on the number of baccalaureate degrees awarded to non-Hispanic Black and Hispanic students divided by the total degrees awarded - excluding those awarded to non-resident aliens and unreported.

Pell-Grant recipients are defined as those students who have received a Pell grant from any SUS Institution within six years of graduation - excluding those awarded to non-resident aliens, who are only eligible for Pell grants in special circumstances. Percentage of Degrees is based on the number of baccalaureate degrees awarded to Pell recipients, as shown above, divided by the total degrees awarded - excluding those awarded to non-resident aliens.

Notes on Trends: In 2007, the US Department of Education re-classified the taxonomy for self-reported race/ethnicity categories and allowed universities a two-year phase-in process before all institutions were required to report based on the new categories for the 2011-12 academic year. This reclassification will impact trends. 


\section{Section 4 - Undergraduate Education (continued)}

\section{TABLE 4J. Baccalaureate Degrees Without Excess Credit Hours}

\begin{tabular}{lc|cccc} 
& $\mathbf{2 0 1 1 - 1 2 *}$ & $\mathbf{2 0 1 2 - 1 3}$ & $\mathbf{2 0 1 3 - 1 4}$ & $\mathbf{2 0 1 4 - 1 5}$ & $\mathbf{2 0 1 5 - 1 6}$ \\
\hline FTIC & $64 \%$ &. &. & $54 \%$ & $74 \%$ \\
\hline AA Transfers & $68 \%$ & $73 \%$ & $81 \%$ & $82 \%$ & $80 \%$ \\
\hline Other Transfers & $46 \%$ & $69 \%$ & $67 \%$ & $58 \%$ & $70 \%$ \\
\hline TOTAL & $\mathbf{6 0 \%}$ & $\mathbf{7 1 . 2 7} \%$ & $\mathbf{7 5 . 4 2} \%$ & $\mathbf{7 1 . 7 3} \%$ & $\mathbf{7 5 . 6 9 \%}$
\end{tabular}

Notes: This table is based on statute 1009.286 (see link), and excludes certain types of student credits (e.g., accelerated mechanisms, remedial coursework, non-native credit hours that are not used toward the degree, non-native credit hours from failed, incomplete, withdrawn, or repeated courses, credit hours from internship programs, credit hours up to 10 foreign language credit hours for transfer students in Florida, and credit hours earned in military science courses that are part of the Reserve Officers' Training Corps (ROTC) program). This metric is not the same as the Excess Hours Surcharge, which has multiple cohorts with varying fee rates. This table reports the percentage of baccalaureate degrees awarded within $110 \%$ of the catalog hours required for a degree based on the Board of Governors Academic Program Inventory. This calculation is based on Hours To Degree data submitted by universities to the Board of Governors which excludes those who previously earned a baccalaureate degree.

Note*: Improvements were made to data collection process beginning with 2012-13 data to better account for high school dual enrolled credits that are exempt from the excess hour calculation. Also, 2012-13 data marked a slight methodological change in how the data is calculated. Each CIP code's required number of 'catalog hours' was switched to the officially approved hours as reported within the Board of Governors' Academic Program Inventory - instead of the catalog hours reported by the university on the HTD files.

\section{TABLE 4K. Undergraduate Course Offerings}

\begin{tabular}{cccccc} 
& Fall 2011 & Fall 2012 & Fall 2013 & Fall 2014 & Fall 2015 \\
\cline { 2 - 4 } & 135 & 127 & 135 & 160 & 155
\end{tabular}

\section{Percentage of Undergraduate Course Sections by Class Size}

\begin{tabular}{lccccc}
\hline Fewer than 30 Students & $77 \%$ & $81 \%$ & $85 \%$ & $83 \%$ & $79 \%$ \\
\hline 30 to 49 Students & $20 \%$ & $15 \%$ & $11 \%$ & $16 \%$ & $18 \%$ \\
\hline 50 to 99 Students & $2 \%$ & $3 \%$ & $4 \%$ & $2 \%$ & $3 \%$ \\
\hline 100 or More Students & $1 \%$ & $1 \%$ & $0 \%$ & $0 \%$ & $0 \%$ \\
\hline
\end{tabular}

Notes: This data is based on Common Data Set (CDS) definitions. According to CDS, a "class section is an organized course offered for credit, identified by discipline and number, meeting at a stated time or times in a classroom or similar setting, and not a subsection such as a laboratory or discussion session. Undergraduate class sections are defined as any sections in which at least one degree-seeking undergraduate student is enrolled for credit. Exclude distance learning classes and noncredit classes and individual instruction such as dissertation or thesis research, music instruction, or one-to-one readings. Exclude students in independent study, co-operative programs, internships, foreign language taped tutor sessions, practicums, and all students in one-on-one classes. 


\section{Section 4 - Undergraduate Education (continued)}

TABLE 4L. Percentage of Undergraduate Credit Hours Taught by Instructor Type

\begin{tabular}{lccccc} 
& $\mathbf{2 0 1 1 - 1 2}$ & $\mathbf{2 0 1 2 - 1 3}$ & $\mathbf{2 0 1 3 - 1 4}$ & $\mathbf{2 0 1 4 - 1 5}$ & $\mathbf{2 0 1 5 - 1 6}$ \\
\hline Faculty & $65 \%$ & $62 \%$ & $63 \%$ & $62 \%$ & $64 \%$ \\
\hline Adjunct Faculty & $34 \%$ & $37 \%$ & $36 \%$ & $34 \%$ & $31 \%$ \\
\hline Graduate Students & $0 \%$ & $1 \%$ & $0 \%$ & $1 \%$ & $1 \%$ \\
\hline Other Instructors & $1 \%$ & $0 \%$ & $1 \%$ & $3 \%$ & $3 \%$ \\
\hline
\end{tabular}

Note: The total number of undergraduate state fundable credit hours taught will be divided by the undergraduate credit hours taught by each instructor type to create a distribution of the percentage taught by each instructor type. Four instructor types are defined as faculty (pay plans 01, 02, and 22), OPS faculty (pay plan 06), graduate student instructors (pay plan 05), and others (all other pay plans). If a course has more than one instructor, then the university's reported allocation of section effort will determine the allocation of the course's total credit hours to each instructor. The definition of faculty varies for Tables 4L, 4M and 4N. For Faculty Teaching Undergraduates, the definition of faculty is based on pay plans 01, 02, and 22.

\section{TABLE 4M. Student/Faculty Ratio}

$\begin{array}{cccccc} & \text { Fall 2011 } & \text { Fall 2012 } & \text { Fall 2013 } & \text { Fall 2014 } & \text { Fall 2015 } \\ \text { Ratio } & 15 & 15 & 13 & 13 & 13\end{array}$

Note: This data is based on Common Data Set (CDS) definitions. This is the Fall ratio of full-time equivalent students (full-time plus $1 / 3$ part time) to full-time equivalent instructional faculty (full time plus $1 / 3$ part time). The ratio calculations exclude both faculty and students in stand-alone graduate or professional programs such as medicine, law, veterinary, dentistry, social work, business, or public health in which faculty teach virtually only graduate-level students. Undergraduate or graduate student teaching assistants are not counted as faculty. 


\section{Section 4 - Undergraduate Education (continued)}

\section{TABLE 40. Post-Graduation Metrics}

\section{Percent of Bachelor's Graduates Employed or Continuing their Education, One Year After Graduation}

\begin{tabular}{lccccc} 
& $\mathbf{2 0 1 0 - 1 1}$ & $\mathbf{2 0 1 1 - 1 2}$ & $\mathbf{2 0 1 2 - 1 3}$ & $\mathbf{2 0 1 3 - 1 4}$ & $\mathbf{2 0 1 4 - 1 5}$ \\
\hline Employed (\$25,000+) or Enrolled & $\mathrm{n} / \mathrm{a}$ & $\mathrm{n} / \mathrm{a}$ & $65.52 \%$ & $62.81 \%$ & $69.6 \%$ \\
Employed (Full-time) or Enrolled & $71 \%$ & $72 \%$ & $76 \%$ & $73 \%$ & $80 \%$ \\
Percent Found & $91 \%$ & $89 \%$ & $92 \%$ & $92 \%$ & $91 \%$ \\
Number of States Included & 1 & 36 & 38 & 38 & 41
\end{tabular}

Notes: Enrolled or Employed (Earning $\mathbf{\$ 2 5 , 0 0 0 + )}$ is based on the number of recent baccalaureate graduates who are either employed, and earning at least $\$ 25,000$, or continuing their education within one year after graduation. Enrolled or Employed Full-Time is based on the number of recent baccalaureate graduates who are either employed full-time or continuing their education within one year after graduation. Full-time employment is based on those who earned at least as much as a full-time (40hrs a week) worker making minimum wage in Florida.

The employed data includes non-Florida data that is available from the Wage Record Interchange System 2 (known as "WRIS 2") and Federal employee data that is available from the Federal Employment Data Exchange System (FEDES) initiative. Military employment data was collected by the Board of Governors staff from university staff. Due to limitations in the data, the continuing enrollment data includes any enrollment the following year regardless of whether the enrollment was post-baccalaureate or not. Percent Found refers to the percentage of graduates found in the dataset - including those that did not earn wages above the full-time threshold and those who were found outside of the one-year window.

For more information about the methodology see: http://www.flbog.edu/about/budget/performance funding.php. For more information about WRIS2 see: http://www.doleta.gov/performance/wris 2.cfm. For more information about FEDES see: http://www.ubalt.edu/fififedes/.

\section{Median Wages of Bachelor's Graduates Employed Full-time, One Year After Graduation}

\begin{tabular}{|c|c|c|c|c|c|}
\hline & $2010-11$ & 2011-12 & 2012-13 & 2013-14* & 2014-15* \\
\hline 5th PERCENTILE WAGE & $\$ 16,400$ & $\$ 18,100$ & $\$ 18,200$ & $\$ 18,800$ & $\$ 19,900$ \\
\hline 25th PERCENTILE WAGE & $\$ 25,300$ & $\$ 25,800$ & $\$ 26,000$ & $\$ 27,700$ & $\$ 28,900$ \\
\hline MEDIAN WAGE & $\$ 33,600$ & $\$ 33,200$ & $\$ 36,000$ & $\$ 36,200$ & $\$ 39,000$ \\
\hline 75th PERCENTILE WAGE & $\$ 44,100$ & $\$ 41,300$ & $\$ 46,700$ & $\$ 46,200$ & $\$ 50,900$ \\
\hline 95th PERCENTILE WAGE & $\$ 62,000$ & $\$ 62,700$ & $\$ 64,500$ & $\$ 70,300$ & $\$ 88,400$ \\
\hline Percent Found & $61 \%$ & $62 \%$ & $62 \%$ & $61 \%$ & $68 \%$ \\
\hline
\end{tabular}

Notes: Median Wage data is based on annualized Unemployment Insurance (UI) wage data for those graduates who earned at least as much as a fulltime employee making minimum wage in the fiscal quarter a full year after graduation. This UI wage data does not include individuals who are selfemployed, employed out of state, employed by the military or federal government, or those without a valid social security number. This wage data includes graduates who were both employed and enrolled. Wages rounded to nearest hundreds. Percent Found refers to the percentage of graduates found in the dataset - including those that did not earn wages above the full-time threshold and those who were found outside of the one-year window.

Note*: The Board approved a change to this metric that uses wage data from all states that participate in the Wage Record Interchange System 2 (known as "WRIS 2"). This methodology change applies only to the wages for 2013-14 and 2014-15 baccalaureate recipients. 


\section{Section 5 - Graduate Education}

TABLE 5A. Graduate Degree Program Changes in AY 2015-16

\begin{tabular}{|l|c|c|c|c|c|c|}
\hline \multicolumn{1}{|c|}{ Title of Program } & $\begin{array}{c}\text { Six-digit } \\
\text { ClP } \\
\text { Code }\end{array}$ & $\begin{array}{c}\text { Degree } \\
\text { Level }\end{array}$ & $\begin{array}{c}\text { Date of } \\
\text { UBOT } \\
\text { Action }\end{array}$ & $\begin{array}{c}\text { Starting } \\
\text { or Ending } \\
\text { Term }\end{array}$ & $\begin{array}{c}\text { Date of } \\
\text { Board of } \\
\text { Governors } \\
\text { Action }\end{array}$ & Comments \\
\hline New Programs & & & & & \\
\hline none & & & & \\
\hline Terminated Programs & & & & \\
\hline Exceptional Student Education & 13.1001 & Masters & $6 / 4 / 2015$ & 2015 FALL & & \\
\hline Programs Suspended for New Enrollments & & & \\
\hline None & \\
\hline
\end{tabular}

Note: This table does not include new majors or concentrations added under an existing degree program CIP Code. This table reports the new and terminated program changes based on Board action dates between May 5, 2015 and May 4, 2016.

New Programs are proposed new degree programs that have been completely through the approval process at the university and, if appropriate, the Board of Governors. Does not include new majors or concentrations added under an existing degree program CIP Code.

Terminated Programs are degree programs for which the entire CIP Code has been terminated and removed from the university's inventory of degree programs. Does not include majors or concentrations terminated under an existing degree program CIP Code if the code is to remain active on the academic degree inventory.

Programs Suspended for New Enrollments are degree programs for which enrollments have been temporarily suspended for the entire CIP Code, but the program CIP Code has not been terminated. Does not include majors or concentrations suspended under an existing degree program CIP Code if the code is to remain active on the academic degree inventory and new enrollments in any active major will be reported. Programs included in this list may have been suspended for new enrollments sometime in the past and have continued to be suspended at least one term of this academic year.

New Programs Considered by University But Not Approved includes any programs considered by the university board of trustees, or any committee of the board, but not approved for implementation. Also include any programs that were returned prior to board consideration by the university administration for additional development, significant revisions, or re-conceptualization; regardless of whether the proposal was eventually taken to the university board for approval. Count the returns once per program, not multiple times the proposal was returned for revisions, unless there is a total re-conceptualization that brings forward a substantially different program in a different CIP Code. 


\section{Section 5 - Graduate Education (continued)}

TABLE 5B. Graduate Degrees Awarded

\begin{tabular}{lccccc} 
& $\mathbf{2 0 1 1 - 1 2}$ & $\mathbf{2 0 1 2 - 1 3}$ & $\mathbf{2 0 1 3 - 1 4}$ & $\mathbf{2 0 1 4 - 1 5}$ & $\mathbf{2 0 1 5 - 1 6}$ \\
\hline First Majors & 72 & 60 & 55 & 50 & 53 \\
Second majors & 0 & 0 & 0 & 0 & 0 \\
\hline TOTAL & $\mathbf{7 2}$ & $\mathbf{6 0}$ & $\mathbf{5 5}$ & $\mathbf{5 0}$ & $\mathbf{5 3}$ \\
\hline Masters and Specialist (1st majors) & 72 & 60 & 55 & 50 & 53 \\
Research Doctoral (1st majors) & 0 & 0 & 0 & 0 & 0 \\
Professional Doctoral (1st majors) & 0 & 0 & 0 & 0 & 0 \\
\hline Dentistry & 0 & 0 & 0 & 0 & 0 \\
Law & 0 & 0 & 0 & 0 & 0 \\
Medicine & 0 & 0 & 0 & 0 & 0 \\
Nursing Practice & 0 & 0 & 0 & 0 & 0 \\
Pharmacy & 0 & 0 & 0 & 0 & 0 \\
Physical Therapist & 0 & 0 & 0 & 0 & 0 \\
Veterinary Medicine & 0 & 0 & 0 & 0 & 0 \\
Other Professional Doctorate & 0 & 0 & 0 & 0 & 0
\end{tabular}

Note: This table reports the total number of graduate level degrees that were awarded by academic year as well as the number by level. The table provides a breakout for some of the Professional Doctoral degrees.

\section{TABLE 5C. Graduate Degrees Awarded in Areas of Strategic Emphasis}

[Includes Second Majors]

\begin{tabular}{lccccc} 
& $\mathbf{2 0 1 1 - 1 2}$ & $\mathbf{2 0 1 2 - 1 3}$ & $\mathbf{2 0 1 3 - 1 4}$ & $\mathbf{2 0 1 4 - 1 5}$ & $\mathbf{2 0 1 5 - 1 6}$ \\
\hline STEM & 0 & 0 & 0 & 0 & 0 \\
\hline HEALTH & 0 & 0 & 0 & 0 & 0 \\
\hline GLOBALIZATION & 0 & 0 & 0 & 0 & 0 \\
\hline EDUCATION & 31 & 18 & 15 & 6 & 13 \\
\hline GAP ANALYSIS & 0 & 0 & 0 & 0 & 0 \\
\hline SUBTOTAL & 31 & 18 & $\mathbf{1 5}$ & $\mathbf{6}$ & $\mathbf{1 3}$ \\
\hline PSE PERCENT OF TOTAL & $\mathbf{4 3 . 0 6 \%}$ & $\mathbf{3 0 . 0 0 \%}$ & $\mathbf{2 7 . 2 7 \%}$ & $\mathbf{1 2 . 0 0 \%}$ & $\mathbf{2 4 . 5 3 \%}$
\end{tabular}

Notes: This is a count of graduate degrees awarded within specific Areas of Strategic Emphasis, as determined by the Board of Governors staff with consultation with business and industry groups and input from universities. This is a count of graduate degrees awarded within specific Programs of Strategic Emphasis, as determined by the Board of Governors staff with consultation with business and industry groups and input from universities - for more information see: http://www.flbog.edu/pressroom/strategic emphasis/. The Board of Governors revised the list of Programs of Strategic Emphasis in November 2013, and the new categories were applied to the historical degrees. A student who has multiple majors in the subset of targeted Classification of Instruction Program codes will be counted twice (i.e., double-majors are included). Note: The denominator used in the percentage includes second majors. 


\section{Section 6 - Research and Economic Development}

TABLE 6A. Research and Development

\section{R\&D Expenditures}

Total (S\&E and non-S\&E)

$(\$ 1,000 s)$

Federally Funded

(\$1,000s)

Percent Funded

From External Sources

Total R\&D Expenditures

Per Full-Time, Tenured,

Tenure-Earning Faculty Member
2010-11

2011-12

2012-13

2013-14

2014-15

$\$ 914$

$\$ 784$

$\$ 1,041$

$\$ 1,026$

$\$ 1,595$

$\$ 191$

$\$ 115$

$\$ 15$

$\$ 6$

$\$ 57$

$31 \%$

$20 \%$

$4 \%$

$1 \%$

$10 \%$

Notes: R\&D Expenditures are based on the National Science Foundation's annual Survey of R\&D Expenditures at Universities and Colleges (data include Science \& Engineering and non-Science \& Engineering awards). Percent Funded from External Sources is defined as funds from federal, private industry and other sources (non-state and non-institutional funds). Total R\&D expenditures are divided by fall, full-time tenured/tenure-track faculty as reported to IPEDS (FGCU includes both tenured/tenure-track and non-tenure/track faculty). The fall faculty year used will align with the beginning of the fiscal year (e.g., 2007 FY R\&D expenditures are divided by fall 2006 faculty). 